\title{
The Impact of the Opinions of the Independent Auditors on the Investor Decisions in Banking Sector: An Empirical Study on the Banks Operating in Turkey
}

\author{
Basak Erdem Rena ${ }^{1}$, Elif Guneren Genc ${ }^{2} \&$ Fatma Ulucan Ozkul $^{3}$ \\ ${ }^{1}$ Department of Accounting and Auditing, Istanbul Commerce University, Istanbul, Turkey \\ ${ }^{2}$ Department of International Trade, Istanbul Commerce University, Istanbul, Turkey \\ ${ }^{3}$ Department of International Finance, Bahcesehir University, Istanbul, Turkey \\ Correspondence: Elif Guneren Genc, Department of International Trade, Istanbul Commerce University, Istanbul, \\ Turkey.
}

Received: December 16, 2015

Accepted: January 18, 2016

Online Published: January 20, 2016

doi:10.5430/afr.v5n1p157

URL: http://dx.doi.org/10.5430/afr.v5n1p157

\begin{abstract}
The opinion of the independent audit has significant importance in decreasing the information risk and increasing the reliability of the information submitted in the financial tables that form the basis of the decisions reached by financial information users. This study is focused on at which degree the individual and institutional investors with whom the banks are in trading relationship is be affected by the opinions of the auditors given as a result of an independent audit.

Whether the deposits imbursed by the people and institutions to the banks as the processes reflecting the trading relations of the banks, the credits they get and the total assets that are affected depending on them, net interest income, trading profit/loss and net profit/loss items and the prices of equity share are affected from these opinions has been examined in the study, The scope of data includes activities of 10 different banks operating in Turkey between the years 2006-2014 have been examined and dynamic panel data model has been used. In the study, it is shown that the independent audit report opinions reinforce the investor decision in the same direction based on given variables.
\end{abstract}

Keywords: Audit opinion, Dynamic panel, Banks

JEL Classifications: C23, M42, G21

\section{Introduction}

The banking sector is one of the basic elements of the financial system. Banks mediate the relationship between fund demanders and fund suppliers by means of the existent payments system and undertake a very important function in economic terms by taking charge in the process of converting the savings into investment within the financial system. Banks should establish a relation based on mutual trust with all its shareholders on the condition that it will start with their customers whose deposits they collect for the purpose of creating resources to be able to sustain their activities. Assuring the public in regards to the operations as well as profits of the banks is of high importance since it assigns more responsibility to bank auditing as a whole. Auditor's opinion carries much significance in the eye of both the investors and the stakeholders. This is due to the fact that auditor's reports have a positive effect on the confidence degree of the stakeholders in the financial statements. Investor's process ofmaking a decision is influenced by the report provided by the independent auditors. The final outcome of an auditor's report, which may be unqualified/qualified/adverse/ disclaimer may either attract or defer the investor, which is a powerful influence that is taken into consideration by the investors.

In the developed markets, the opinion of the independent auditor is one of the elements that affect the decisions of the investor. Significant changes are experienced in the field of audit in recent years in Turkey. Together with these changes, it is aimed that the institutions and organizations with activities in Turkey should be more transparent with the information they make public. In this regard accountability and reliability is highly important. The issue of whether the independent auditor opinion given to the banks that are subject to the independent audit and that issues financial tables in accordance with International Financial Reporting Standards as of 2005 in our country affect the decisions of the investors could be accepted as the indicator of the trust for the audit results. Before proceeding to the literature and research part of the study, the definitions of these changes taking place in the banking literature are 
given. Deposit is defined as the domestic or foreign money invested by the real or legal entities to the banks at any moment they desire or at the end of a certain period of time or by conforming to a certain notification period on condition that they shall draw it back together with its interest. Credits are defined as the banks to give its financial resources to the people or institutions that are in need in return for a price. Total assets show the total of the receivables and the assets owned by the banks. The distribution of the assets expresses how the funds collected from various resources are used in banking activities. Net interest income is the net sum that remains after deducting the interest expenses they pay to the foreign resources provided by the banks from the interest incomes stemming from the use of their resources in various ways. Trading $\mathrm{P} / \mathrm{L}$ is the net sum remaining after deducting the interest costs, prices and commission expenses from the interest incomes, commission incomes and dividend incomes of the banks. Net $\mathrm{P} / \mathrm{L}$ is the net profit value attained by a bank after the tax. It is a complete scale for assessing the performance of the bank. The price of the equity share is the market price of the equity share extracted by the banks and representing the participation share to the partnership capital.

In this study, for the purpose of being able to reveal this connection, the impact of the independent auditor opinions of 10 banks having activities in our country on the deposit, credit, total assets, trading/net profit and loss, net interest income and prices of equity share has been examined. When the data of 10 banks between 2006-2014 are examined for the purpose of revealing whether this direct proportion is existent in our country, it is concluded that the independent auditor opinions are one of the elements that affect the decisions of the investors.

\section{Literature}

Banks are able to sustain their existence as long as they are trusted and they protect their dignity. However, it has been observed that the financial scandals and economic crises experienced in the banking sector occur as a result of some structural deficiencies. Insufficient audits of the banks, not being able to get benefit from the fact of audit especially at the stage of crediting and the weakness of internal control structure are the main reasons for these structural deficiencies (Yuksel \& Demir). Independent audits in the bank is the activity of reporting the entities and institutions except for the bank, financial condition of the banks and the activity results to the related units of the bank by examining the correctness of their reflection to the financial reports and the conformity of the mentioned reports to the generally accepted accounting principles (Gunduz, 2006). Banks are the financial institutions that could be harmed due to the withdrawal or emptying of the funds by the deposit owners from the bank account. Therefore, making negative statements about the banks makes the profession of auditing harder. If an adverse opinion is reached on a bank as a result of an audit, this situation may have serious impacts on the bank. However, expressing a conditional or negative opinion proves the reliability of the auditor. When the auditor expresses a qualified opinion, the customer is generally aware of the fact that it is possible to lose the bank or a profitable contract (Ojo, 2012).

The independent audit report that is published as a result of the audit of the bank may have an effect on the elements such as deposit collection, crediting activities, equity items in the financial tables and the prices of trading securities/stocks of the banks.

Ojeka (2011) ascertained how the auditor's report can be relied upon in making investment decision. This study investigated the relationship between the auditor's report and the shareholders' investment decision. A survey was applied and a questionnaire is used to gather the data needed. The main sources for the data are the shareholders/stockbrokers and auditors/accountants who work in Nigeria. The population is made up of an estimated figure of 1200 shareholders/stockbrokers and auditors/accountants and the sample size is 300 . The authors have used correlation coefficient to establish the relationship and in the finding a positive relationship exists but weak and mild.

Tahinakis et.al. (2010), conducted a study that takes audit reports from 2005-2007 period for companies with shares on the Athens Stock Exchange (ASE). This study examines the impact an audit report has on a company's stock prices. The results showed that the audit reports do not have unlimited informational content to the benefit of the investors and they do not form part of investor's decision making process

Moradi et.al. (2011), analyzed the correlation between the qualified audit reports and share prices as well as returns. The analysis aims to test the information content of qualified audit report. This study is conducted using a market-based method on the qualified reports of the shareholding companies in Iran between 2005-2009. The analysis was run on the changes in share prices and returns during the test period since the changes measured and analyzed serve in place of the week before and the week after the announcement's date.

Herath and Kumar (2002), analyzed the elements that should take place in the audit of the banks on the basis of the difference in the operation areas of the banks, the dependency on the information technology and the risk structure changing in parallel with the increase of the complexities in the banking activities in the world. In the study conducted on 107 countries in the world, a direct relation has been detected between the necessity for auditing the bank by the authorized audit institution and the developed and developing markets and the countries in which 
off-shore banking activities are sustained. However; no significant relation has been found between the supervision and control of the audit and the development status of the bank and the income level of the country.

In their study, Gaganis and Pasiouras (2007) studied the factors that affect the opinion of the auditor in the banking sector between 1995-2004 in nine Asian countries. In the study conducted through the method of logistic regression, it has been determined that the qualified reports are generally existent in the Asian banks which have smaller and less capital, which are less profitable and which have excessive liquidity.

Ucma and Baycan (2008) studied the historical development of the audit culture in the public banks owning a larger share in the banking sector as of the first years of republic especially due to the insufficiency of the private capital in Turkey. The authors emphasized that the provision of the correctness and reliability of the financial data submitted by the banks could be possible thanks to independent audit and they have also expressed that the independent audit contributes to the social wealth of the society with efficient tax control.

Kanagaretnam, Krishnan, \& Lobo (2010) examined the independency of the auditors by analyzing the relation between the payments given to the auditors and the scope of the profit management by means of the credit compensations in the banking sector. According to the results; no relation was detected between the audit costs unexpected for the great banks and the profit management. The relation between the profit management and the audit costs by means of the extraordinary credit compensations could be a factor that threatens the independency of auditors especially for the small banks.

If a bank has an unqualified audit opinion although it has had many important financial problems in the year before it went bankrupt, the public firstly focuses on the previous years. As the activities of the bank get complex, the expectation of the public from the independent audit increases. Stanisic et.al. (2013) analyzed the relation between auditor reports and the risk of bankruptcy in the banking sector between 2007-2011 in the Serbian Republic. According to the results of the analysis, it has been revealed that the reports that include the explanation paragraph or that are qualified auditor reports should be paid more attention to when compared to other report types. In addition, if the auditor opinion for a bank is unqualified, it has a tendency to go on as unqualified in the next years. Although the authorities of the operation determine the qualified audit reports as more explicit red flag when compared to unqualified audit report, it has been revealed that the unqualified reports that include explanation paragraph are also significant red flags.

In their study, Onyekwelu and Ugwuanyi (2014) assessed the impact of the independent audit on the deposit collection activity in the banking sector in Nigeria. The data used in the study were collected by means of face to face interview technique and questionnaires having been carried out with the shareholders, workers and customers of the bank. According to the results of the study the independent auditors significantly contribute to the growth of the deposit by providing reasonable assurance. In addition, the independent audit reports encourage the deposit owners and lead the deposits of other bank authorities to the banking sector. Among the examined audit reports, it has been observed that no report has caused any panic impact among the deposit owners. In the audit, the authors express that the audit quality that increases together with the independency of the auditor shall provide the protection of the deposit needed by the deposit owners and shall increase the interest of other authorities in the sector.

Jibrin, Blessing, \& Danjuma (2014) examined the role of the accountants and independent auditors in the banking crisis experienced in Nigeria by means of the case study together with the theory and application of the qualified audit reports that have become a questionable issue in the banking sector of Nigeria. The inclusion of the accountants and auditors in the unethical activities of the operation especially in the crisis period has drawn the attention of the public to the deficiencies in the applications. It has been focused on the fact that the audit reports are the proofs clearly and obviously transmitted to the public regarding the bank, but they give little information on the operational processes and organizational values of the bank.

Dantas et.al. (2014) compared the audit arrangements in the banking system with an empirical analytical study. In the comparison, the arrangements of 172 countries attained from the World Bank have been taken as the basis and level of the audit arrangements in the banking institutions and the properties of the national banking systems have been studied. According to the results of the explanatory statistical results, the nations in which the arrangements in the highest level are existent are the most developed ones among Central Asia, North Africa, and European countries. When the regression results are assessed in terms of the properties of the banking sector and the arrangements of audit, it is seen that there are audit arrangements in higher level in the countries in which the national credit compensations are high in the banks and more profitable banks apply more sanctions regarding the performance of the auditors of the more profitable banks. Moreover, it has been revealed that there are less bank audit arrangements in the countries in which the public banks are included in the financial system less and more sanctions have been brought to the banking activities. 


\section{Methodology}

This study has focused on at what degree the individual and institutional investors with whom the banks are in trading relations are affected by the opinions of the auditors published as a result of the independent audit. Because the financial markets are under the influence of mostly the past experiences and old behavior patterns, taking the delayed values of the variables and the explanatory factors into consideration while examining has become significantly important (Velinov\&Chen 2015, Caporole, Hunter \& Faek, 2014, Thorbecke, 2014, Liow 2006 vb.). For this purpose; in the study, dynamic panel data model has been used to determine the impacts of the delayed period effects in the examination of the impact of the independent audit opinions.

Dynamic panel data models could be examined under two groups as autoregressive panel data models and the panel data models whose delay has been distributed. In the autoregressive panel data models, while the delayed values of the dependent variables take place as independent variables; the delayed values of the independent variables take place at the side of the independent variables in the panel data models whose delay has been distributed. Dynamic panel data models are generally examined as auto-regressive panel data models.

$$
Y_{i t}=\alpha_{i}+\gamma Y_{i, t-1}+\beta X_{i t}^{\prime}+v_{i t} \quad \mathrm{i}=1,2, \ldots, \mathrm{N} \text { (individuals), } \quad \mathrm{t}=1,2, \ldots, \mathrm{T} \text { (time) }
$$

Here; $v_{i t}=\mu_{i}+u_{i t}$

In the model $\left(Y_{i t}\right)$ delayed value of the dependent variable takes place at the side of the independent variables $\left(X_{i t}^{\prime}\right)$, and $\mu_{i}$ expresses the unit impact. In the dynamic models, the internality problem is faced in the event that there is a relation between $Y_{i, t-1}$ and $u_{i t-1}$ due to especially the previous shocks. Under this condition; the estimators that are based on Ordinary Least Squares (OLS) and Generalized Least Squares (GLM) are biased and inconsistent (Bond, $2002,5)$. A solution to terminate the internality problem is the use of instrumental variables regression method (Guris, 2015).

In the dynamic models, Anderson and Hsiao (1982) are the first to suggest instrumental variables regression method for the purpose of terminating the internality problem that occurs due to the relation between the delayed dependent variable and the error term. Anderson and Hsiao (1982) have suggested to exclude the $\mu_{i}$ unit impacts from the model and to use $\left(\Delta Y_{i, t-1}\right)$ instead of $\left(\Delta Y_{i, t-2}\right)$ or $\left(Y_{i, t-2}\right)$ as the instrumental variable with the first differenced method. The validity of the suggested instrumental variables is dependent on $\Delta Y_{i, t-2}$ or $Y_{i, t-2}$ to be in high correlation with $\Delta Y_{i, t-1}$, uncorrelated with $\Delta u_{i t}$ and $u_{i t}$ to be with no auto-correlation. In this way, consistent, but inefficient estimators have been attained.

On a similar note, Arellano and Bond (1991) estimated a model with more instrumental variables by using the moments of the dependent variable that includes all of its possible delayed values in the event that $u_{i t}$ has autocorrelation (Zeren and Ergun, 2010, 77). These estimations have unbiased and smaller variance with single-staged Generalized Method of Moments (GMM) and two-staged GMM (Garza, Bucheli and Munoz, 2011). However, according to the used instrumental variable method; the efficiencies of the estimators show an alteration. Arellano and Bover (1995) have suggested the instrumental variable regression model by using the "orthogonal deviations" method. Blundell and Bond (1998) have suggested an alternative method. Blundell and Bond have focused on the situation in which $\mathrm{T}=3,(\mathrm{~N}>\mathrm{T})$ and $E=\left(Y_{i l} \Delta u_{i 3}\right)=0$ condition of orthogonality is existent and they have emphasized the importance of the extra moment condition to attain the active estimator of the dynamic panel data model. Windmeijer (2005) has expressed that modified instrumental variable should be used based on the fact that the standard errors give biased results under heteroscedasticity. In this study, because the first differenced method has become weak and $\mathrm{N}>\mathrm{T}$, the instrument variable method suggested by Arellano-Bover (1995) and Blundell-Bond (1998) has been used among the dynamic panel data models.

\section{Implementation}

In this study; two different points of view are tested to determine the impact of auditor opinions on the investments made to banks. The first is the examination of whether the trading relations of the banks with the entities or institutions that are their customers are affected from these opinions. The variables such as deposit imbursed by the entities and institutions to the banks, the credits they get and the total assets that will get affected depending on them, net interest income, trading $\mathrm{P} / \mathrm{L}$ and net $\mathrm{P} / \mathrm{L}$ items have been used as the processes that reflect the trading relations of the banks. The second is the examination of whether those who make investments in the banks are affected by these opinions. The prices of the equity shares have been used for this situation as variables. In the study the impact of only the auditor opinions have been tried to be determined by accepting the impacts of all other variables as fixed.

In the study, the variables such as deposits (DP), credits (CR), total assets (TA), net interest incomes (NII), net trading profit/loss (NTPL) and net profit/loss (NPL) items, prices of equity shares and the opinions of the independent auditors take place for 10 banks that conduct processes permanently in Borsa Istanbul between 2006-2014 and that show activities in Turkey. The opinions of the independent auditors have been examined in the 
banks that have been included in the study between 2006-2014 and it has been detected that no bank has taken any adverse reports. It has been determined that the report has been given as unqualified or qualified, and they have been classified by giving 1 to the unqualified report and 0 to the qualified report. The data used in this study have been arranged from the official website of FOREX and the opinions published as a result of the independent audit report have been arranged from "Public Disclosure Platform". (The independent audit reports belonging to 2009 and before this year have been attained from stock market of Istanbul website.) The used banks are given in Attachment-1.

The descriptive statistics regarding the used variables are given in Table 1. The deposit average of 10 banks has been found as $3.98 \mathrm{E}+10$ and the standard deviation of the credits have been found as $3.61 \mathrm{E}+10$. Net trading loss has been determined as minimum $-3.60 \mathrm{E}+08$ for 10 banks having been examined together with this, the maximum value for the interest income has been determined as $8.80 \mathrm{E}+08$.

Table 1. Descriptive statistics

\begin{tabular}{ccccc}
\hline Variables & Mean & Std. Dev. & Min & Max \\
\hline DP & $3.98 \mathrm{E}+10$ & $3.58 \mathrm{E}+10$ & $1.10 \mathrm{E}+09$ & $1.30 \mathrm{E}+11$ \\
CR & $3.49 \mathrm{E}+10$ & $3.61 \mathrm{E}+10$ & $5.80 \mathrm{E}+07$ & $1.60 \mathrm{E}+11$ \\
TA & $6.66 \mathrm{E}+10$ & $6.27 \mathrm{E}+10$ & $2.00 \mathrm{E}+09$ & $2.40 \mathrm{E}+11$ \\
NII & $2.49 \mathrm{E}+09$ & $2.13 \mathrm{E}+09$ & $4.70 \mathrm{E}+07$ & $1.10 \mathrm{E}+10$ \\
NPL & $1.14 \mathrm{E}+09$ & $1.09 \mathrm{E}+09$ & 9400000 & $3.40 \mathrm{E}+08$ \\
NTPL & $5.04 \mathrm{E}+07$ & $2.20 \mathrm{E}+08$ & $-3.60 \mathrm{E}+08$ & $8.80 \mathrm{E}+08$ \\
SP & 3.018111 & 2.135709 & 0.39 & 9.02
\end{tabular}

In this study, dynamic panel data estimators have been used to be able to examine the impact of the change in the previous period of the banks. In this way, the impacts of the dynamic structure on the variables have empirically become observable. The results related to the models formed with all the variables are summarized in Table 2 .

Table 2. Results regarding the models

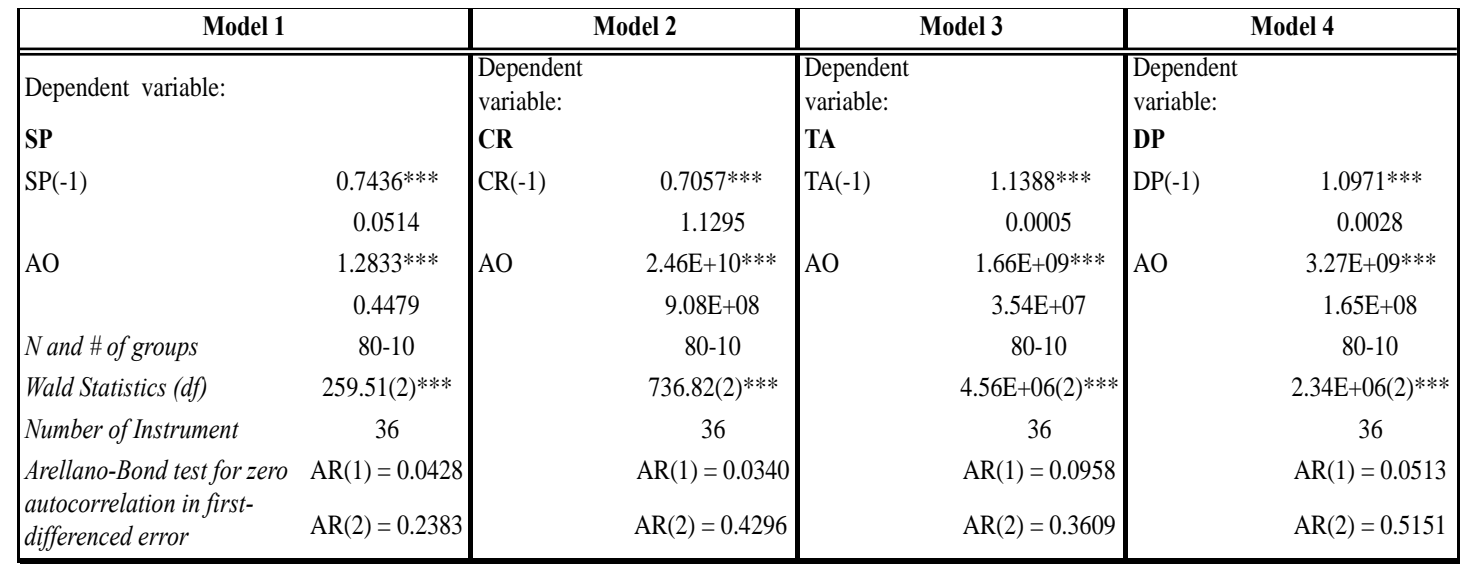

\begin{tabular}{|c|c|c|c|c|c|}
\hline \multicolumn{2}{|l|}{ Model 5} & \multicolumn{2}{|c|}{ Model 6} & \multicolumn{2}{|c|}{ Model 7} \\
\hline Dependent variable: & & $\begin{array}{l}\text { Dependen } \\
\text { variable: }\end{array}$ & & $\begin{array}{l}\text { Dependen } \\
\text { variable: }\end{array}$ & \\
\hline NII & & NPL & & NTPL & \\
\hline NII(-1) & $0.5905^{* * *}$ & $\mathrm{NP}(-1)$ & $0.2446^{* * *}$ & NTI(-1) & $0.9334 * * *$ \\
\hline & 0.0128 & & 0.0047 & & 0.0021 \\
\hline $\mathrm{AO}$ & $1.32 \mathrm{E}+09^{* * *}$ & $\mathrm{AO}$ & $6.37 \mathrm{E}+07 * * *$ & $\mathrm{AO}$ & $1.24 \mathrm{E}+08$ \\
\hline & $8.33 \mathrm{E}+07$ & & 2535365 & & 5027883 \\
\hline$N$ and \# of groups & $80-10$ & & $80-10$ & & $80-10$ \\
\hline Wald Statistics (df) & $31863.22(2) * * *$ & & $16193(2)^{* * *}$ & & $1.77 \mathrm{E}+06$ \\
\hline Number of Instrument & 36 & & 36 & & 36 \\
\hline Arellano-Bond test for zero & $\mathrm{AR}(1)=0.2220$ & & $\mathrm{AR}(1)=0.0379$ & & $\mathrm{AR}(1)=0.0925$ \\
\hline $\begin{array}{l}\text { autocorrelation in first- } \\
\text { differenced error }\end{array}$ & $\mathrm{AR}(2)=0.2265$ & & $\mathrm{AR}(2)=0.1100$ & & $\mathrm{AR}(2)=0.5299$ \\
\hline
\end{tabular}

***,** and $*$ indicates significance at $1 \%, 5 \%$ and $10 \%$ statistical levels respectively. 
The existence of the first order autocorrelation is frequently encountered in the dynamic panel data models and this condition is deemed as normal due to the own structure of the model. $\operatorname{AR}(1)$ and $\operatorname{AR}(2)$ tests showing whether autocorrelation is existent have been applied in the models. The existence of first order autocorrelation has been detected in the models. However, no finding of second order autocorrelation was encountered. The absence of second order autocorrelation shows the consistency of the GMM estimators. At the same time, because it has been determined that the standard errors of the estimation results calculated with GMM are deviant, works have been conducted with robust errors. According to the results attained from the study, the Wald test that shows the statistical meaningfulness of the model is meaningful in all the models. Moreover, when the statistical meaningfulness of the parameters is examined, it is seen that all the variables are meaningful.

The variable of auditor opinion is statistically meaningful and positive in the dynamic panel data models formed for the variables such as deposits, credits, total assets, net interest incomes, net trading profit/loss and net profit/loss items and the prices of equity shares. This condition shows that the reports of an independent auditor opinion given to the banks as unqualified has an improving impact on the variables when compared to the reports of independent auditor opinion given as qualified. When other variables are deemed as fixed, it is seen that the independent auditor opinions are one of the factors that change the decision of investors in the same direction on the variables such as deposits, credits, total assets, net interest incomes, net trading profit/loss and net profit/loss items and the prices of equity shares attained from the financial tables.

\section{Conclusions}

Banks mediate to the fund demanders and fund suppliers by means of the existent payments system and undertake a very important function in economical terms by taking charge in the process of converting the savings into investment within the financial system. Banks should establish a relationship based on mutual trust with all its shareholders on condition that it shall start with their customers whose deposits they collect for the purpose of creating resources to be able to sustain their activities.

The importance of independent audit is incontrovertibly important in the provision of this trust. The investors in developed countries are affected from the independent auditor opinions in direct proportion during their decision making processes. When the data of 10 banks between 2006-2014 are examined for the purpose of revealing whether this direct proportion is existent in our country, it is concluded that the independent auditor opinions are one of the elements that affect the decisions of the investors.

\section{Appendix 1}

The Banks Examined in the Study; Akbank - Alternatif Bank - Finansbank - Garanti Bank - Is Bank C - Sekerbank - Tekstil Bank - Turk Economics Bank - Vakifbank - Yapi Kredi Bank

\section{References}

Anderson, T.W. \& Hsiao, C. (1982). Formulation and estimation for dynamic models using panel data. Journal of Econometrics, 18, 47-82. http://dx.doi.org/10.1016/0304-4076(82)90095-1

Arellano, M., \& Bond, S. (1991). Some tests of specification for panel data: Monte Carlo evidence and an application to employment equations. The Review of Economic Studies, 58(2), 277-297. http://dx.doi.org/10.2307/2297968

Arellano, M., \& Bover, O. (1995). Another look at the instrumental varible estimation of error-components models. Journal of Econometrics, 68, 29-51. http://dx.doi.org/10.1016/0304-4076(94)01642-D

Blundell, R., \& Bond. S. (1998). Initial conditions and moment restrictions in dynamic panel data models, Journal of Econometrics, 87, 115-143. http://dx.doi.org/10.1016/S0304-4076(98)00009-8

Caporale, G.M., Hunter J., \& Faek, A. (2014), On the linkages between stock prices and exchange rates: Evidence from the banking crisis of 2007-2010. International Review of Financial Analysis, 33. 87-103. http://dx.doi.org/10.1016/j.irfa.2013.12.005

Dantas, J.A., Costa, F.M., Niyama, J.K., Medeiros, O.R. (2014). Audit regulation in banking systems: analysis of the international context and determining factors, 25(64). http://dx.doi.org/10.1590/S1519-70772014000100002

Gaganis, C. \& Fotios, P. (2007). A multivariate analysis of the determinants of auditors opinions on Asian banks. Managerial Auditing Journal, 22(3), 268-287. http://dx.doi.org/10.1108/02686900710733143

Garza, P.B., Bucheli, M. \& Munoz, T.G. (2011). Dynamic panel data: A useful technique in experiments. The Papers Series: 10/22. http://hdl.handle.net/10481/31576 
Gunduz, E. (2006) Banks and insurance accounting. Eskisehir Anadolu University Publications.

Guris, S. (2015). Panel Data Models with STATA. Der Publication, Istanbul, Turkey.

Herath H. \& Pranesh K., (2002). External audit requirements of banking systems around the world, 10th Pacific Basin Finance, Economics and Accounting (PBFEA) Annual Conference, Singapore.

Jibrin, M. S., Blessing, S. E., \& Danjuma, I. (2014). The Role of Auditors in the Recent Nigerian Banking Crisis. International Journal of Academic Research in Business and Social Sciences, 4(3), 231-251. http://dx.doi.org/10.6007/IJARBSS/v4-i3/703

Kanagaretnam, K., Krishnan, G. V., \& Lobo, G. J. (2010). An Empirical Analysis of Auditor Independence in the Banking Industry. Accounting Review , 86(6), 2011-20146. http://dx.doi.org10.2308/accr.2010.85.6.2011

Liow, K.H. (2006). Dynamic relationship between stock and property markets. Applied Financial Economics, 16(5), 371-376. http://dx.doi.org/10.1080/09603100500390885

Moradi, M., Salehi, M., Rigi, M., \& Moeinizade, M. (2011). The effect of qualified audit report on share prices and returns: Evidence of Iran. African Journal of Business Management, 5(8), 3354-3360. http://dx.doi.org/10.5897/AJBM10.1456

Ojeka, S. (2011). Analyzing The Relationship between Auditor's Report and Shareholders' Investment Decision. Germany: LAP Lambert Academic Publishing Gmbh \& Co. KG Deutschland. ISBN: 978-3-8443-3150-9.

Ojo, M. (2012). Auditor independence-its importance to the external auditor's role in banking regulation and supervision, Lambert Academic Publishing.

Onyekwelu., U.L., \& Uche B. U. (2014). External auditing relevance in the growth of banking industry in Nigeria: An emphasis on the effect on deposit mobilization. European Journal of Accounting, Auditing and Finance Research, 2(3), 54-68.

Robu, M. A., \& Robu, I. B. (2015). The influence of audit report on the relevance of accounting information reported by listed Romanian companies. Procedia Economics and Finance, 20, 562-570. http://dx.doi.org/10.1016/S2212-5671(15)00109-4

Stanisic, M.,et.al. (2013). Analysis of auditor's reports and bankruptcy risk in banking sector in the Republic of Serbia. Amfiteatru Economic, 15(34),431-441.

Tahinakis , P., Mylonakis , J., \& Daskalopoulou , E. (2010). An Appraisal of the Impact of Audit Qualifications on Firms' Stock Exchange Price Fluctuations. Journal Name Enterprise Risk Management, 1(1), 86-99. http://dx.doi.org/10.5296/erm.v2i1.335

Thorbecke, W. (2014). The contribution of the yen appreciation since 2007 to the Japanese economic debacle. Journal of the Japanese and International Economies, 31, 1-15. http://dx.doi.org/10.1016/j.jjie.2013.12.004

Ucma, T., \& Mehmet B. (2008) Development of independent auditing in state banks in Turkey from Past to future, Journal of Yasar University, 3(12), 1711-1730.

Velinov, A., \& Chen, W. (2015). Do stock prices reflect their fundamentals? New evidence in the aftermath of the financial crises. Journal of Economics and Business, 80, http://dx.doi.org/10.1016/j.jeconbus.2015.02.001

Windmeijer, F. (2005). A finite sample correction for the variance of linear efficient two-step GMM estimators. Journal of Econometrics, 126, 25-51. http://dx.doi.org/10.1016/j.jeconom.2004.02.005

www.borsaistanbul.com.tr

Yuksel A. \& Volkan D. (2011). Bankalarda Denetim Ve Iç Kontrol Yapisi Eksikliğinin Sonucu: Finansal Kriz. Mali Çözüm Dergisi, 55, (1-10).

Zeren, F. \& Ergun S. (2010). The Determinants of Foreign Direct Investment Flows in EU: Dynamic Panel Data Analysis. Business and Economics Research Journal, 1(4), 67-83. 